American Journal of Applied Sciences 5 (8): 909-916, 2008

ISSN 1546-9239

(C) 2008 Science Publications

\title{
Three-Phase Shunt Active Power Filter
}

\author{
${ }^{1}$ Moleykutty George and ${ }^{2}$ Kartik Prasad Basu \\ ${ }^{1}$ Faculty of Engineering and Technology, Multimedia University, 75450 Melaka, Malaysia \\ ${ }^{2}$ Faculty of Engineering, Multimedia University, 63100 Cyberjaya, Malaysia
}

\begin{abstract}
Active power filters have been widely used for harmonic elimination. The performance of a conventional three-phase shunt Active Power Filter (APF) using Synchronous Detection Method (SDM) has been compared with Nonlinear Autoregressive-Moving Average (NARMA)-L2 based APF. The novelty of this study lies in the application of NARMA-L2 control to generate the amplitude of the reference supply current required by the APF circuit and the successful implementation of the APF system for harmonic elimination. The entire system has been modeled using MATLAB 6.1 toolbox. Simulation results demonstrate the applicability of NARMA-L2 controller for the control of APF.
\end{abstract}

Key words: APF, NARMA-L2, VSI, harmonics, THD, SDM, power quality

\section{INTRODUCTION}

Power Quality (PQ) is an important measure of an electrical power system. The term PQ means to maintain purely sinusoidal current wave form in phase with a purely sinusoidal voltage wave form. The power generated at the generating station is purely sinusoidal in nature. The deteriorating quality of electric power is mainly because of current and voltage harmonics due to wide spread application of static power electronics converters, zero and negative sequence components originated by the use of single phase and unbalanced loads, reactive power, voltage sag, voltage swell, flicker, voltage interruption etc.

To improve the power quality traditional compensation methods such as passive filters, synchronous capacitors, phase advancers, etc. were employed. However traditional controllers include many disadvantages such as fixed compensation, bulkiness, electromagnetic interference, possible resonance etc.. These disadvantages urged power system and power electronic engineers to develop adjustable and dynamic solutions using custom power devices. Custom power devices are power conditioning equipments using static power electronic converters to improve the power quality of distribution system customers. These include $\mathrm{APF}^{[1-11]}$, dynamic voltage restorer (DVR $)^{[12-16]}$ and Unified Power Quality Conditioner (UPQC) ${ }^{[17-21]}$. APF is a shunt compensator used to eliminate the disturbances in current, whereas DVR is a series compensator used to eliminate the disturbances in voltage. Recently UPQC, which consists of both shunt and series compensators is proposed as a one shot solution for power quality problems.

This study proposes the effectiveness of NARMA-L2 controller for the control of APF system. The novelty of this paper lies in the application of NARMA-L2 controller for the determination of amplitude of reference supply current required in an APF system. This paper also discusses the control of APF system using SDM. The control strategies of APF system are detailed in the second part of this paper. Simulation results in the third part demonstrate the effectiveness of NARMA-L2 controller for the control of APF system.

\section{CONTROL TECHNIQUES OF APF SYSTEM}

In this section, control scheme of APF system using SDM is discussed and compared with that using NARMA-L2 controller.

Corresponding Author: Moleykutty George, Faulty of Engineering and Technology, Melaka Campus, Multimedia University, 75450, Melaka, Malaysia Tel: +606 2523286 Fax: +606-231 6552 


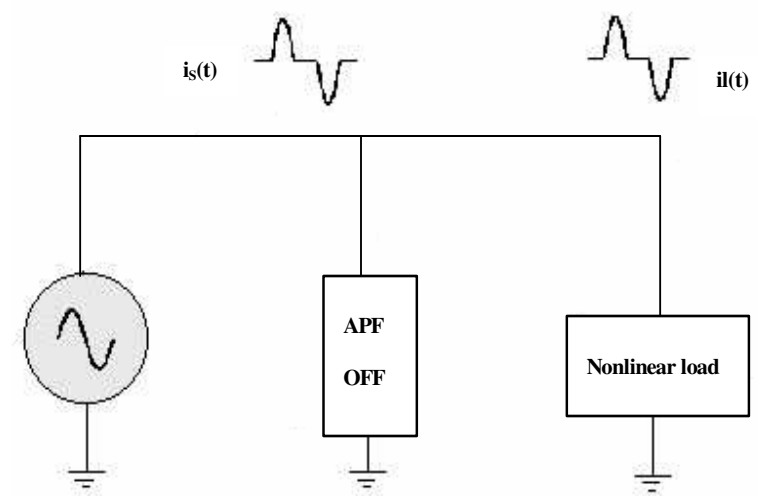

Fig. 1: Block diagram of a simple power system with APF OFF

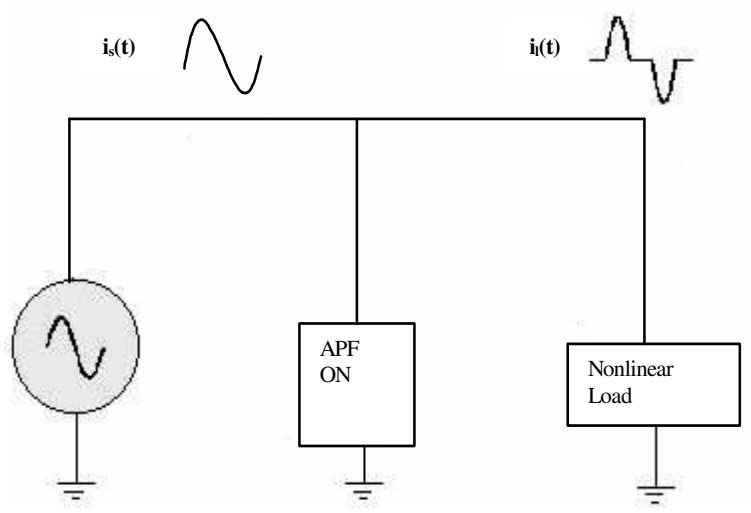

Fig. 2: Block diagram of a simple power system with APF ON

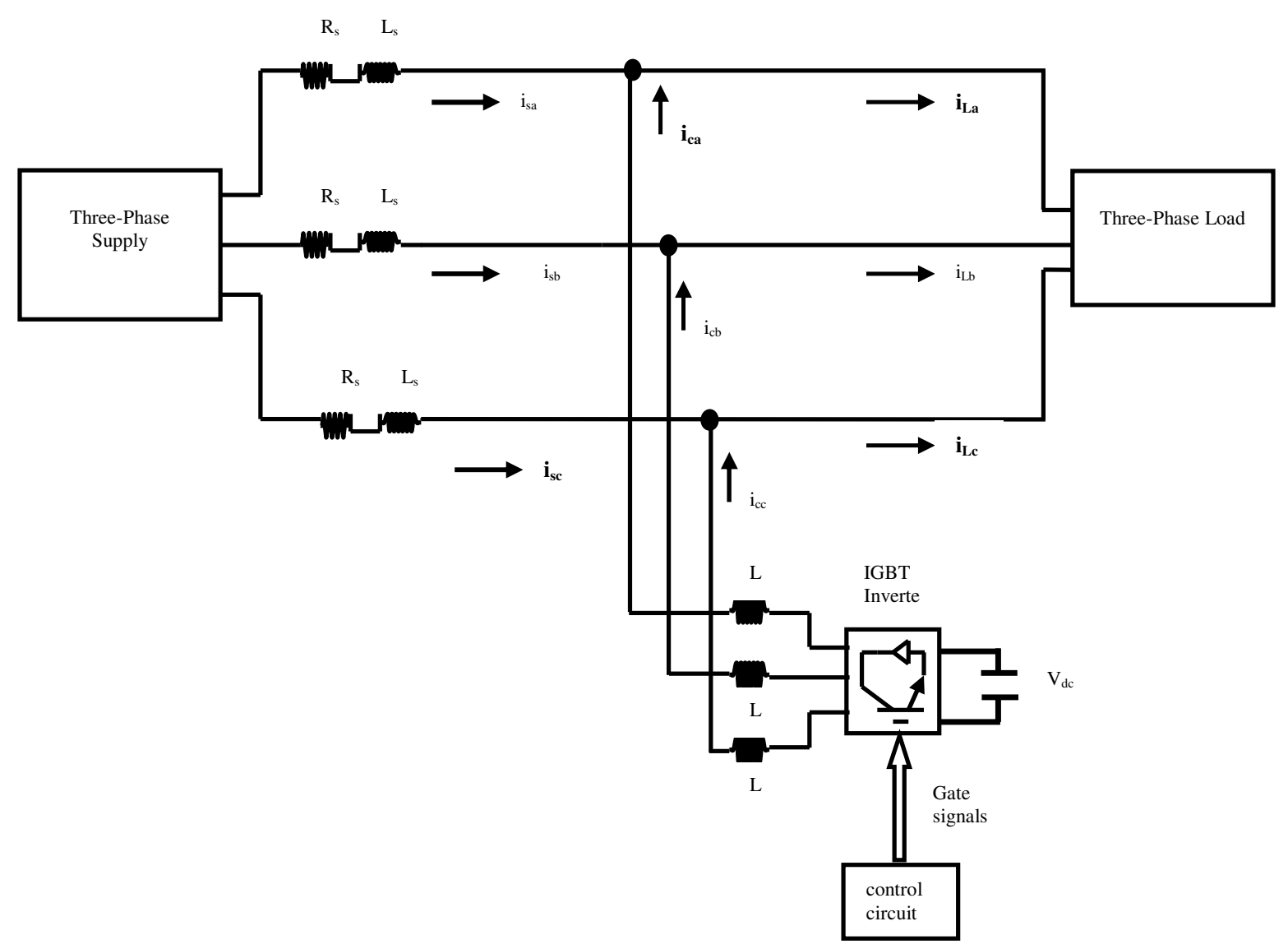

Fig. 3: Schematic diagram of an APF system

Principle of operation: A three-phase system has been selected to study the performance of the APF system. Comparison of Fig. $1^{[22]}$ and $2^{[22]}$ shows the compensation principle of a shunt active power filter.
APF injects a current equal in magnitude but in phase opposition to harmonic current. Figure 3 shows the block diagram of a three-phase APF system. The heart of the APF system is the IGBT based Voltage 


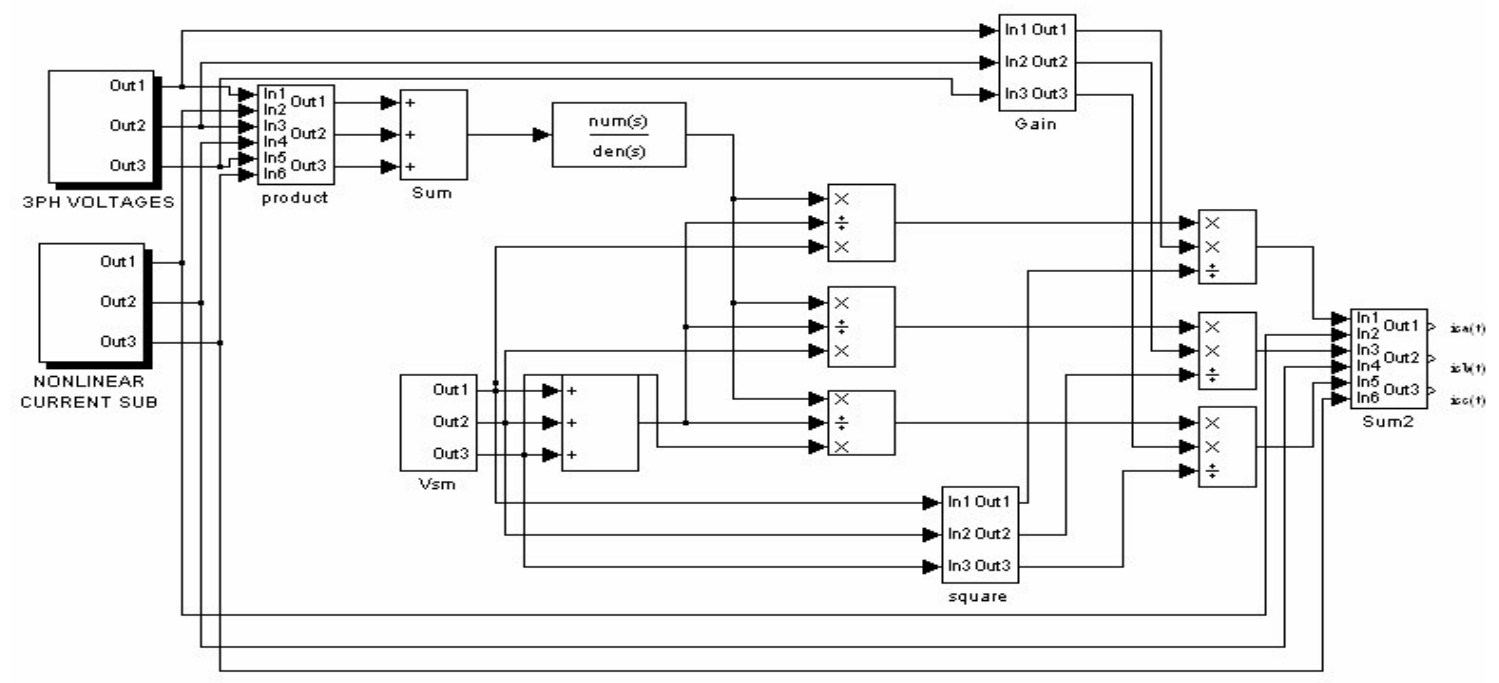

Fig. 4: Simulink Model of the control circuit using SDM

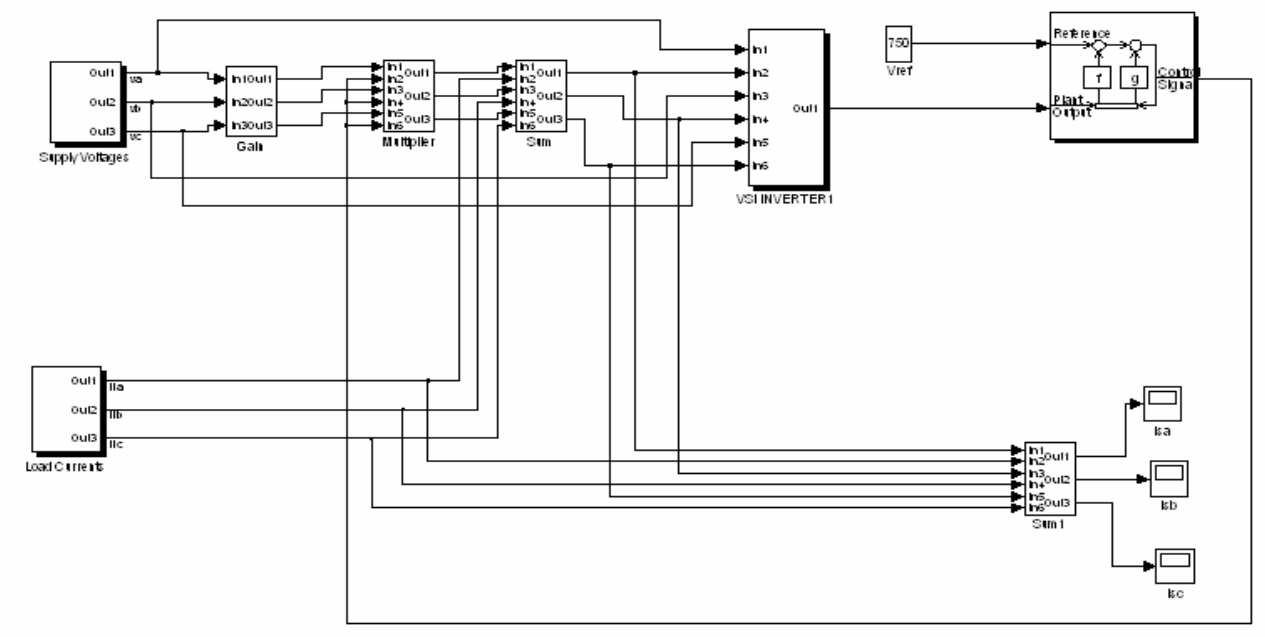

Fig. 5: Simulink model of NARMA-L2 controlled APF

Source Inverter (VSI). A dc capacitor is used to deliver power for the VSI. For the successful operation of APF, capacitor voltage should be at least $150 \%$ of maximum line-line supply voltage.

Control of APF system using SDM: Figure 4 shows the control circuit of an APF system using SDM. The control circuit consists of an outer voltage control loop and two inner current control loops. The outer control loop is used to maintain the capacitor voltage constant and to determine the amplitude of the mains currtents required in an APF system. SDM method is basically used for the determination of amplitude of the source currents. In this algorithm, the three-phase mains currents are assumed to be balanced after compensation. The real power $\mathrm{P}(\mathrm{t})$ consumed by the load could be calculated from the instantaneous voltages and load currents as:

$$
p(t)=\left[\begin{array}{lll}
v_{s a}(t) & v_{s b}(t) & v_{s c}(t)
\end{array}\right]\left[\begin{array}{l}
i_{l a}(t) \\
i_{l b}(t) \\
i_{l c}(t)
\end{array}\right]
$$

where $\mathrm{v}_{\mathrm{sa}}(\mathrm{t}), \mathrm{v}_{\mathrm{sb}}(\mathrm{t}), \mathrm{v}_{\mathrm{sc}}(\mathrm{t})$ are the instantaneous values of supply voltages and $\mathrm{i}_{\mathrm{la}}(\mathrm{t}), \mathrm{i}_{\mathrm{lb}}(\mathrm{t}), \mathrm{i}_{\mathrm{lc}}(\mathrm{t})$ are the instantaneous values of load currents. The average 


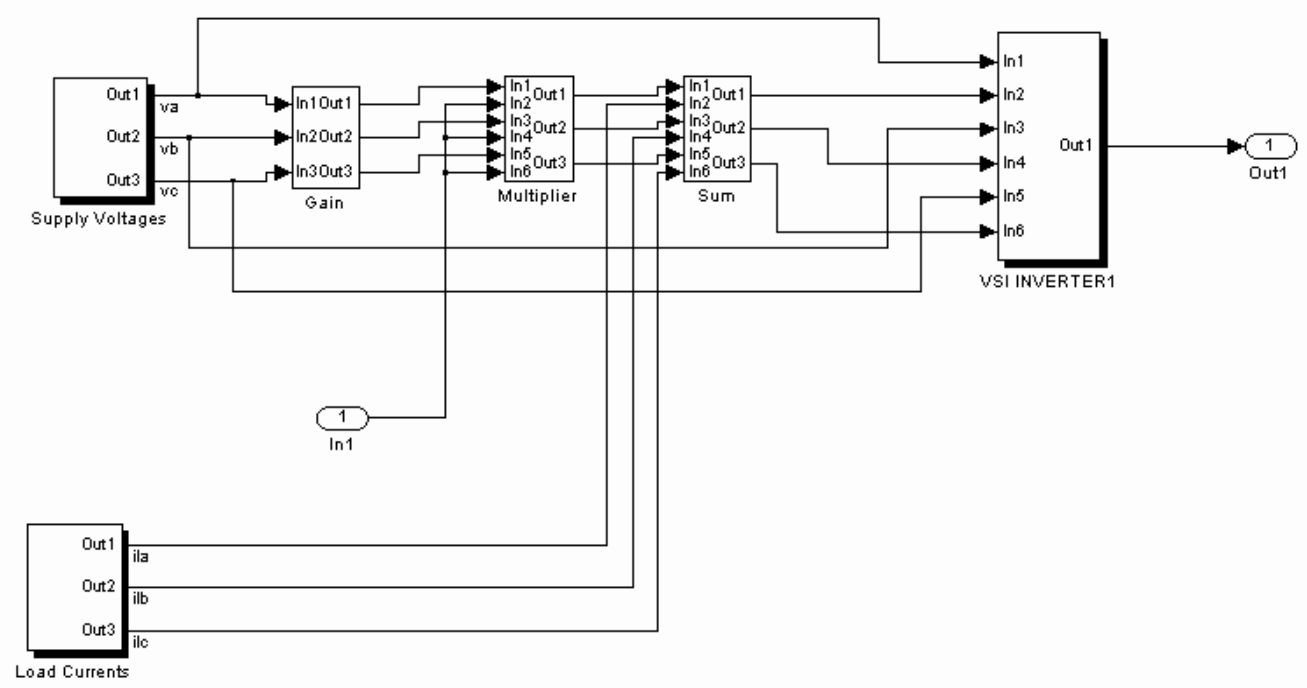

Fig. 6: Plant Model

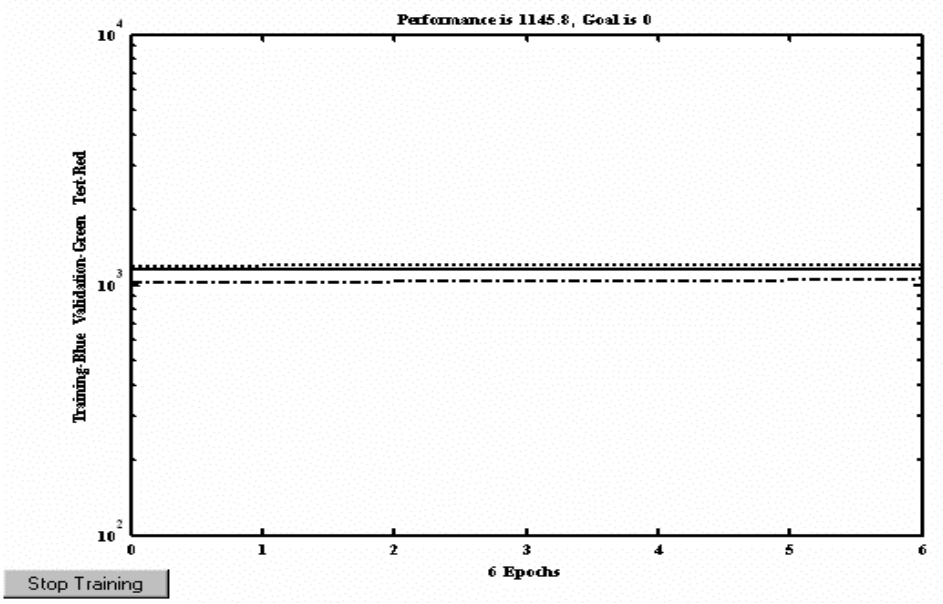

Fig.7: Performance graph

value $\mathrm{P}_{\mathrm{dc}}$ is determined by applying $\mathrm{P}(\mathrm{t})$ to a low pass filter. The real power is then split into the three phases as follows:

$$
\begin{gathered}
\mathrm{i}_{\mathrm{ca}}(\mathrm{t})=\mathrm{i}_{\mathrm{sa}}(\mathrm{t})-\mathrm{i}_{\mathrm{la}}(\mathrm{t}) \\
\mathrm{P}_{\mathrm{b}}=\frac{\mathrm{P}_{\mathrm{dc}} \times \mathrm{V}_{\mathrm{smb}}}{\mathrm{V}_{\mathrm{sma}}+\mathrm{V}_{\mathrm{smb}}+\mathrm{V}_{\mathrm{smc}}}
\end{gathered}
$$

Thus for purely sinusoidal balanced supply voltages,

$$
P_{c}=\frac{P_{d c} \times V_{s m c}}{V_{s m a}+V_{s m b}+V_{s m c}}
$$

$$
\begin{gathered}
\mathrm{P}_{\mathrm{a}}=\mathrm{P}_{\mathrm{b}}=\mathrm{P}_{\mathrm{c}}=\frac{\mathrm{P}_{\mathrm{dc}}}{3} \\
\mathrm{i}_{\mathrm{sa}}(\mathrm{t})=\frac{2 \times \mathrm{v}_{\mathrm{sa}}(\mathrm{t}) \times \mathrm{P}_{\mathrm{a}}}{\mathrm{V}_{\mathrm{sma}}^{2}} \\
\mathrm{i}_{\mathrm{sb}}(\mathrm{t})=\frac{2 \times \mathrm{v}_{\mathrm{sb}}(\mathrm{t}) \times \mathrm{P}_{\mathrm{b}}}{\mathrm{V}_{\mathrm{smb}}{ }^{2}} \\
\mathrm{i}_{\mathrm{sc}}(\mathrm{t})=\frac{2 \times \mathrm{v}_{\mathrm{sc}}(\mathrm{t}) \times \mathrm{P}_{\mathrm{c}}}{\mathrm{V}_{\mathrm{smc}}{ }^{2}}
\end{gathered}
$$

where, $\mathrm{V}_{\text {sma }}, \mathrm{V}_{\text {smb }}, \mathrm{V}_{\text {smc }}$ are the amplitudes of the supply voltages. With the objective of achieving Unity Power Factor (UPF), the desired mains currents are 

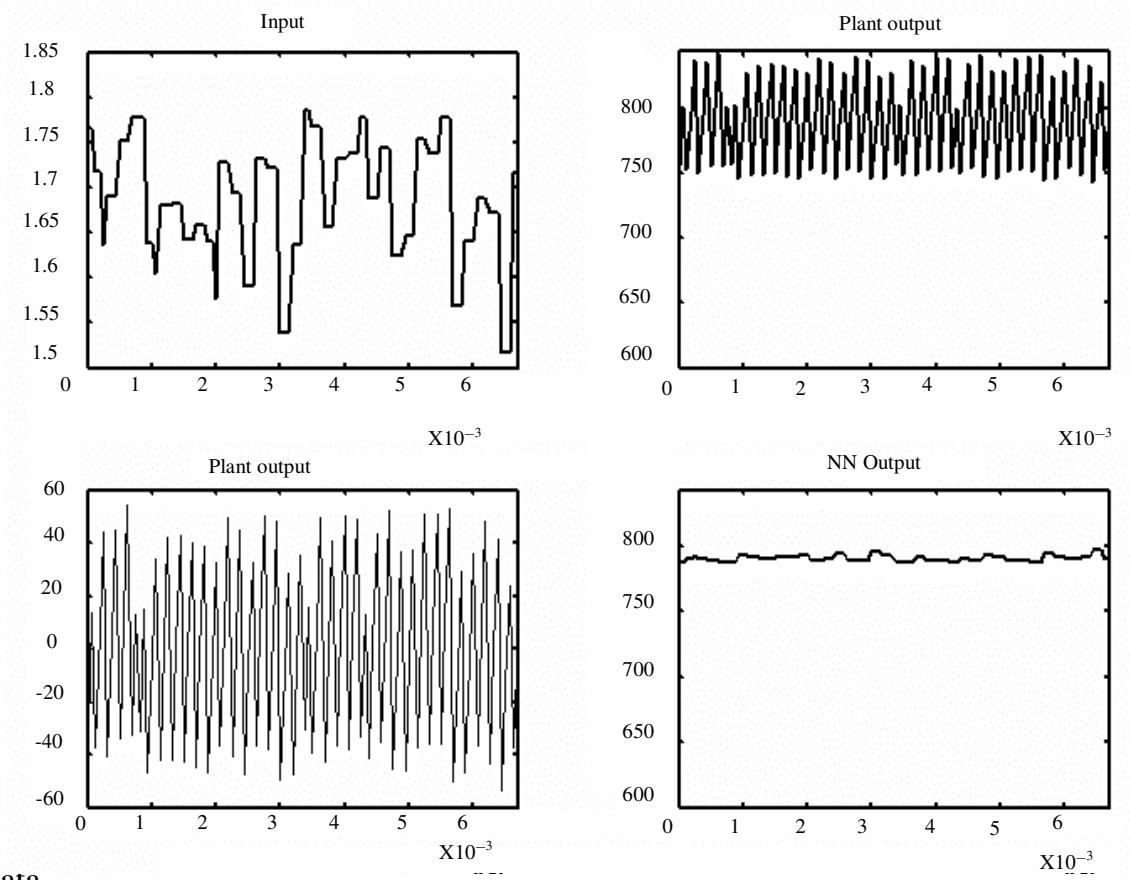

Fig. 8: Training data

obtained by equations $4 \mathrm{a}-\mathrm{c}$. The compensation currents are calculated using equations 5a-5c. Since the PWM VSI is assumed to be instantaneous and infinitely fast to track the compensation currents, it is modeled as a current amplifier with unity gain ${ }^{[23]}$.

$$
\begin{aligned}
& \mathrm{i}_{c a}(t)=i_{s a}(t)-i_{l a}(t) \\
& i_{c b}(t)=i_{s b}(t)-i_{l b}(t) \\
& i_{c c}(t)=i_{s c}(t)-i_{l c}(t)
\end{aligned}
$$

Control of APF system sing NARMA-L2 controller: NARMA-L2 controller ${ }^{[24,25]}$ is successfully used for the control of UPQC ${ }^{[24]}$ and the speed control of separately excited DC motor ${ }^{[25]}$. The simulink model of a NARMA-L2 controlled APF system is shown in Fig. 5. The simulink plant model shown in Fig. 6 is used to train the NARMA-L2 controller. As shown in Fig. 5, the control input of the plant is the amplitude of the desired mains current and the capacitor voltage is the plant output. NARMA-L2 controller checks the desired capacitor voltage and the actual capacitor voltage and the control input is adjusted to achieve the reference value. Table 1 shows the specifications used to train the controller. It has been observed that the complicated equations in SDM could be eliminated by the use of NARMA-L2 controller.

Sample performance graph and training data obtained from a NARMA-L2 controller are illustrated in Fig. 7 and Fig. 8 respectively.
Table 1: Plant model specifications

\begin{tabular}{ll} 
Size of hidden layer & 1 \\
\hline Sampling interval (s) & $6.254 \mathrm{e}^{-5}$ \\
No. of delayed plant inputs & 2 \\
No. of delayed plant outputs & 1 \\
Training samples & 40000 \\
Maximum plant input & 1.8 \\
Minimum plant input & 1.5 \\
Maximum interval value (s) & $8 \mathrm{e}-3$ \\
Minimum interval value (s) & $6.254 \mathrm{e}-5$ \\
Maximum plant output & 800 \\
Minimum plant output & 700 \\
Training Epochs & 100 \\
Training Function & traincgf \\
Use current weights & selected \\
Use validation data & selected \\
Use testing data & selected \\
\hline
\end{tabular}

Table 2: Performance of APF system

\begin{tabular}{lllll}
\hline Controller & $\begin{array}{l}\text { SDM } \\
\alpha^{\circ}=0\end{array}$ & NARMA-L2 & $\begin{array}{l}\text { SDM } \\
\alpha^{\circ}=75\end{array}$ & NARMA-L2 \\
\hline Is_THD (\%) & 0.4 & 0.1 & 5 & 0.2 \\
IL_THD (\%) & 30 & 30 & 33 & 33 \\
Is1 (A) & 5.975 & 7.06 & 0.38 & 7.04 \\
Is5 (A) & 0.009 & 0 & 0 & 0 \\
Is7 (A) & 0.01 & 0 & 0 & 0 \\
Is11 (A) & 0.018 & 0 & 0 & 0 \\
Is13 (A) & 0.012 & 0 & 0 & 0 \\
I11 (A) & 5.98 & 6 & 1.54 & 1.54 \\
I15 (A) & 1.19 & 1.2 & 0.45 & 0.46 \\
I17 (A) & 0.86 & 0.85 & 0.05 & 0.05 \\
I111 (A) & 0.53 & 0.5 & 0.135 & 0.14 \\
Il13 (A) & 0.57 & 0.45 & 0.04 & 0.04 \\
DPF & 0.9999 & 0.9999 & 0.9999 & 0.9999 \\
\hline
\end{tabular}


Am. J. Applied Sci., 5 (8): 909-916, 2008

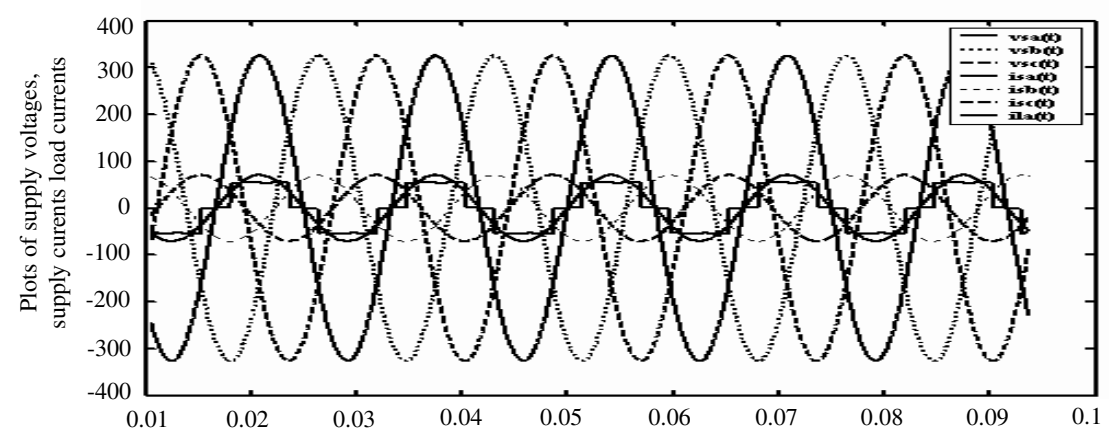

Fig. 9: Plots of v,(t) (A), I,(t) (A), i(t)(A)

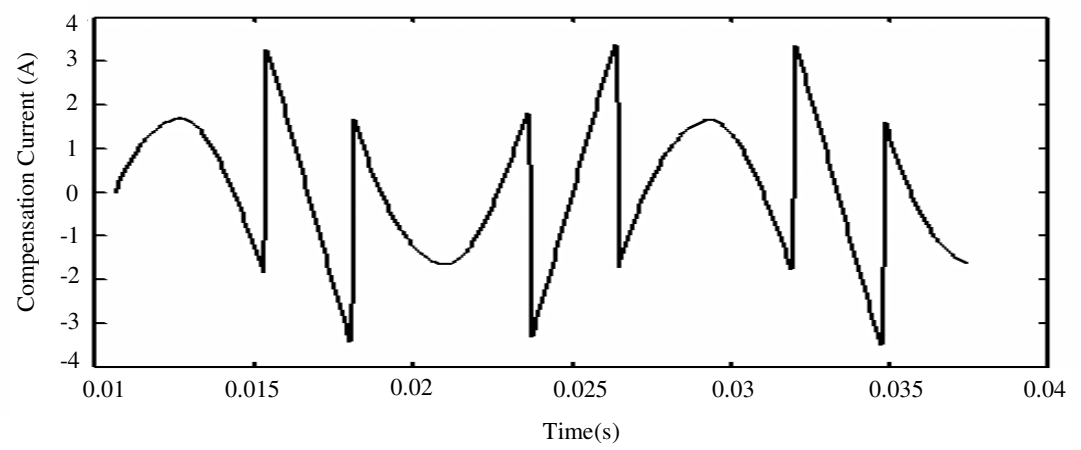

Fig. 10: Plot of Compensation current (A)

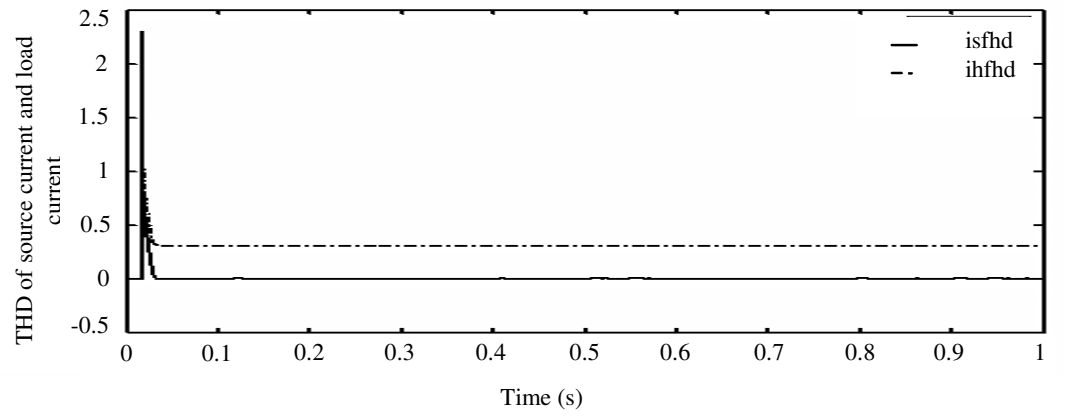

Fig. 11: THD of source and load currents

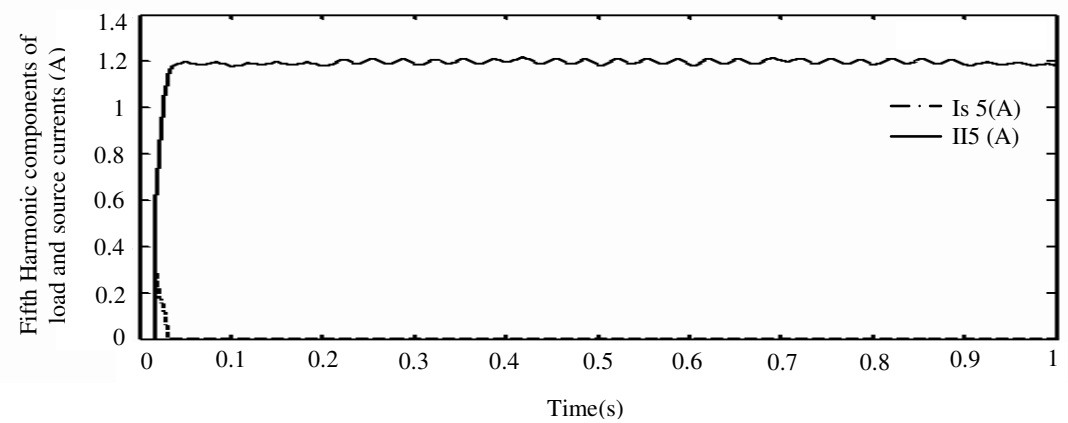

Fig. 12: 5th harmonic components of source and load currents (A)

\section{RESULTS AND DISCUSSION}

NARMA-L2 controller has been successfully modeled and tested for the control of APF system.
MATLAB 6.1 toolbox is used to model the system. The effectiveness of the system has been tested for various firing angles $(\alpha)$ in the range of $0^{\circ}$ and $90^{\circ}$. The performance of the developed system 
Am. J. Applied Sci.. 5 (8): 909-916. 2008

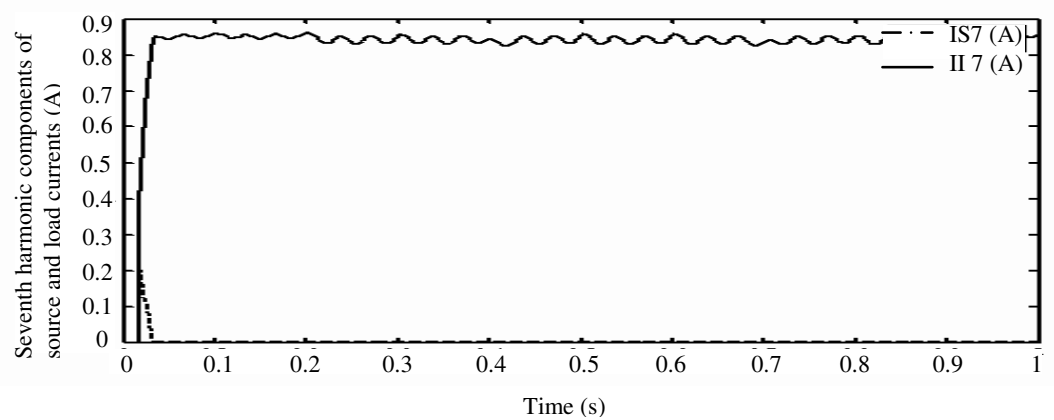

Fig. 13: 7th harmonic components of source and load currents (A)

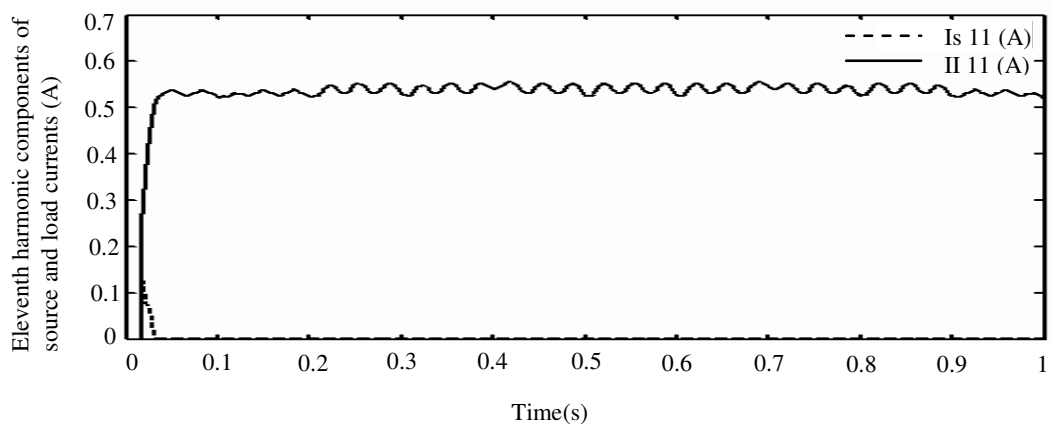

Fig. 14: $11^{\text {th }}$ harmonic components of source and load currents

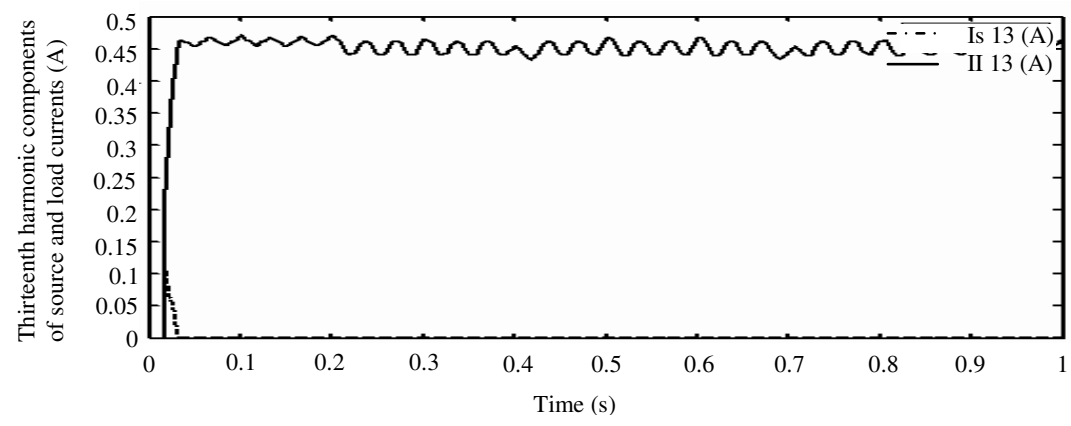

Fig. 15: $13^{\text {th }}$ harmonic components of source and load currents

is illustrated with the one using SDM for two different firing angles as tabulated in Table 2. Simulation results for $\alpha=0^{\circ}$ shown in Fig. 9 and Fig. 15 demonstrate the effectiveness of the developed system for the control of APF.

\section{CONCLUSION}

A NARMA-L2 controlled APF system has been modeled and successfully tested for the control of APF. The novelty of this paper lies in the application of NARMA-L2 controller to determine the amplitude of the reference source current required in an APF system. This paper also discusses modeling and control of APF system using SDM. The performance of the different system has been compared. It has been observed that the complicated calculations used in SDM could be eliminated by the use of NARMA-L2 controller.

\section{ACKNOWLEDGMENT}

The authors are grateful to Alan Tan Wee Chiat, Dr. Abdulazeez S. Boujarwah, Christo George, Prof. K Ramar and Dr. Saurabh Kumar Mukerji for valuable discussions.

\section{REFERENCES}

1. Hirofumi Akagi, 1994. Trends in Active Power Line Conditioners: IEEE Tran. Power Electronics, 9: 263-268. 
2. Janko Nastran, Rafael Cajhen, Matija Seliger and Peter Jereb, 1994. Active Power Filter for Nonlinear AC Loads: IEEE Trans. Power Electronics, 9: 92-96.

3. E. Destobbeleer and L. Protin, 1996. On the Detection of Load Active Currents for Active Filter Control: IEEE Trans. Power Electronics, 11: 768-775.

4. Mauricio Aredes, Jurgen Hafner and Klemens Heumann, 1997. Three-Phase Four-Wire Shunt Active Filter Control Strategies: IEEE Trans. Power Electronics, 12: 311-318.

5. Hideaki Fujita and Hirofumi Akagi, 1998. The Unified Power Quality Conditioner: The Integration of Series and Shunt-Active Filters: IEEE Tran. Power Electronics, 13: 315-322.

6. Fang Zheng Peng, W.Jr.Ott. George and J. Adams Donald, 1998. Harmonic and Reactive Power Compensation Based on the Generalized Instantaneous Reactive Power Theory for ThreePhase Four-Wire Systems: IEEE Trans. Power Electronics, 13: 1174-1181.

7. Kishore Chatterjee, B.G. Fernandes and K. Gopal Dubey, 1999. An Instantaneous Reactive Volt-Ampere Compensator and Harmonic Suppressor System: IEEE Trans. Power Electronics, 14: 381-392.

8. Po-Tai Cheng, Subhashish Bhattacharya and D. Deepak Divan, 1999. Line Harmonics Reduction in High-Power Systems Using Square-Wave Inverters-Based Dominant Harmonic Active Filter: IEEE Trans. Power Electronics, 14: 265-272.

9. Shyh-Jier Huang and Wu. Jinn-Chang, 1999. A Control Algorithm for Three-Phase Three-Wired Active Power Filters Under Nonideal Mains Voltages: IEEE Trans. Power Electronics, 14: 753-760.

10. Ambrish Chandra, Bhim Singh, B.N. Singh and Kamal Al-Haddad, 2000. An Improved Control Algorithm of Shunt Active Filter for Voltage Regulation, Harmonic Elimination, Power-factor Correction, and Balancing of Nonlinear loads: IEEE Trans. Power Electronics, 15: 495-507.

11. Moleykutty George, 2004. Modeling and simulation of a current controlled three-phase shunt active power filter using MATLAB/PSB: AIUB Journal of Science and Engineering, 3: 11-18.

12. Hyosung Kim, Sang-Joon Lee and Seung-Ki Sul, 2004. A calculation for the compensation voltages in dynamic voltage restorers by use of PQR power theory: $19^{\text {th }}$ Annual IEEE Applied Power Electronics Conf. and Expo. 2004, 1: 573-579.
13. J. G. Nielsen, M. Newman, H. Nielsen and F. Blaabjerg, 2004. Control and testing of a dynamic voltage restorer (DVR) at medium voltage level: IEEE Trans. Power Electronics, 19: 806-813.

14. E.K.K. Sng, S.S. Choi and D.M. Vilathgamuwa, 2004. Analysis of series compensation and DC-link voltage controls of a transformerless self-charging dynamic voltage restorer: IEEE Trans. Power Delivery, 19: 1511-1518.

15. M.J. Newman, D.G. Holmes, J.G. Nielsen and F. Blaabjerg, 2005. A Dynamic Voltage Restorer (DVR) with selective harmonic compensation at medium voltage level: IEEE Trans. Ind. Application, 41: 1744-1753.

16. John Godsk Nielsen and Frede Blaabjerg, 2005. A detailed comparison of system topologies for dynamic voltage restorers, IEEE Trans. Ind. Applications, 41: 1272-1280.

17. Leon M. Tolbert, Fang Zheng Peng and G. Thomas Habetler, 2000. A multilevel converter-based universal power conditioner, IEEE Trans. Ind. Applications, 36: 596-603.

18. Arindam Ghosh and Gerard Ledwich, 2001. A unified power quality conditioner for simultaneous voltage and current compensation, Electric power systems research, 59: 55-63.

19. A. Elnady and M.M.A. Salama, 2001. New functionalities of the unified power quality conditioner: IEEE/PES Transmission and Distribution Conf. and Expo., 1: 415-420.

20. R. Faranda and I. Valade, 2002. UPQC compensation strategy and design aimed at reducing losses: IEEE Int. Symposium on Ind. Electronics, 4: 1264-1270.

21. Gu Jianjun, Xu. Dianguo, Liu Hankui and Gong Maozhong, 2002. Unified Power Quality Conditioner (UPQC): the principle, control and application: Proc. Power Conversion Conf. 2002, 1: 80-85.

23. M. Bhasker, 2001. Comparative evaluation of control strategies for three phase active power filters-using MATLAB SIMULINK, Thesis report, Master of Technology, University of Calicut, India pp: 35, unpublished data.

24. Moleykutty George, 2007. Artificial intelligence based three-phase unified power quality conditioner: Journal of computer science, 3: 465-477.

25. Moleykutty George, 2008. Speed control of separately excited dc motor: American journal of applied sciences, 5: 227-233, article in press. 